\title{
Cutaneous Melanoma pT4b TNM Finding v6 and v7
}

National Cancer Institute

\section{Source}

National Cancer Institute. Cutaneous Melanoma pT 4b TNM Finding v6 and v7. NCI

Thesaurus. Code C48853.

Cutaneous melanoma greater than $4.0 \mathrm{~mm}$ in thickness, with ulceration. (from AJCC 6th and 7th Eds.) 